\title{
人工内耳対側耳に補聴器を装用した人工内耳装用児の両耳補聴効果 一人工内耳のみ片耳補聴との比較一
}

\author{
森 尚彫1)2, 伊藤壽一 ${ }^{1)}$, 森 壽子 ${ }^{2 / 3)}$, 平海晴一 ${ }^{1)}$, 山口 忍 ${ }^{14)}$, \\ 石丸 満5), 伊藤恭子 ${ }^{1)}$, 大西晶子 ${ }^{1)}$, 黒田生子 ${ }^{6)}$, 藤本政明 ${ }^{2}$ \\ ${ }^{1}$ 京都大学大学院医学研究科耳鼻咽喉科・頭頚部外科学 \\ 2)藤本耳鼻咽喉科クリニック \\ ${ }^{3)}$ 北海道医療大学大学院心理科学研究科言語聴覚学専攻 \\ ${ }^{4)}$ 姫路獨協大学医療保健学部言語聴覚療法学科 \\ ${ }^{5)}$ 日本赤十字社和歌山医療センター耳鼻咽喉科 \\ ${ }^{6}$ 帝京平成大学健康メディカル学部言語聴覚学科
}

\begin{abstract}
要旨：人工内耳（以下 $\mathrm{CI}$ ) と補聴器 (以下 $\mathrm{HA}$ ）の両耳装用児 5 例 $(\mathrm{CI}+\mathrm{HA}$ 群）と CI のみ片耳装用児 5 例 ( CI 群) の CI 対側耳裸耳聴力, 装用閾值, 語音聴取能力を比較し, CI と HA の両耳装用児と CI のみ片耳装用児の差異点, HA 装用・非装用の理由について 検討し, 以下の知見をえた。

$\mathrm{CI}+\mathrm{HA}$ 群は，CI 対側耳の裸耳聴力が平均 90dBHL台で，CI 群より良好であり，CI+ $\mathrm{HA}$ 群の CI と HA の両耳装用では, CI 単独に比べて語音聴取検査成績の改善を認めた。

$\mathrm{CI}+\mathrm{HA}$ 群では，児が $\mathrm{CI}$ 対側耳への HA 装用を嫌がらず，きこえの改善を自覚してお り，CI群では，児が CI 対側耳への HA 装用に対して否定的であった。

CI 対側耳への HA 装用は，CI 対側耳が HA 装用によって聴覚活用可能かどうかの裸耳 聴力の評価と, CI と HA の両耳装用による補聴効果の評価が重要であり, 児の反応や変 化をよく観察して装用指導する必要があると考えられた。
\end{abstract}

$$
\text { ーキーワードー }
$$

人工内耳, 補聴器, 両耳装用, 両耳補聴効果, 小児

\section{はじめに}

人工内耳（Cochlear Implant, 以下 CI) の普及に より, CI 装用児の数は増加しているが, 現在, CI 装用児において，CI 対側耳に補聴器 (Hearing Aid, 以下 HA）を装用している児と HA を装用していな い児が存在している。

両耳装用に関しては，諸外国では，CI の両耳装

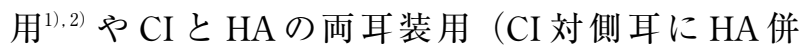

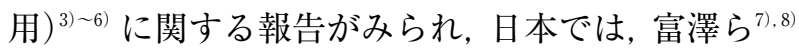
や松代ら ${ }^{9)(10)}$ の報告がみられる。
CI と対側耳 HA の両耳装用による両耳補聴効果 として, Morera $ら^{3)}$, Luntz $~^{4), 6)}$, 松代 ${ }^{9)}$ は, 成 人における騒音下での語音聴取検査を実施し，CI と対側耳 HA の両耳装用による聴取の改善を指摘し ており，成人においては，騒音下でのききとりの向 上等で, $\mathrm{CI}$ と HA の両耳補聴効果はあきらかにな ってきている。しかし, 小児に関しては, Chingら がCI と対側耳 HAの両耳装用によって, 語音聴取 や方向感，コミュニケーション面で改善されるとい う報告 ${ }^{11)}$ や富澤らが CI と対側耳 HA の両耳装用に よって, 両耳融合効果があるという報告7),8 
れるものの，小児における CI と HAの両耳補聴効 果に関する報告は多くはない。

そこで本研究では, 小児における, CI と対側耳 HA の両耳装用による両耳補聴効果, 特に, 対側耳 に HA を装用する効果や意義をあきらかにするため に, CI と対側耳 HA の両耳装用児と CI のみ片耳装 用児の CI 対側耳裸耳聴力，およびそれぞれの装用 状態での装用閾值と語音聴取能力を比較し，CI と 対側耳 HA の両耳装用児とCI のみ片耳装用児の差 異と, HA 装用・非装用の理由について検討した。

\section{対象}

対象とした症例は，言語能力の発達に遅滞がな く, 語音聴取検查の実施と, CI 対側耳の HA 装用 効果の感想や HA 非装用の理由について応答可能で あった10例である。言語発達については, ウェクス ラー式知能検査（WISC-III）で算出した言語性知 能（Verbal Intelligence Quotient，以下 VIQ)，扔よ び絵画語彙発達検查 (Picture Vocabulary Test) で 算出した語彙理解力の評価点 (Scaled Score, 以下 SS）が平均以上（VIQ90 以上， SS8 以上）で，これ らの検査は，語音聴取検査と同時期（語音聴取検査 から 3 カ月以内）に実施した。全例，言語獲得前失 聴で，遺伝子検査等の精査はうけておらず，失聴原 因は不詳である。いずれも CI 埋め込み術前は両耳
にHAを装用しており，CI 埋め达み術後 CI と CI 対側耳にHA を併用し，両耳装用をしている5 例を $\mathrm{CI}+\mathrm{HA}$ 群, CI 埋め达み術後, 途中から CI 対側耳 の $\mathrm{HA}$ 装用をやめ, CI のみ片耳装用している 5 例 をCI群とした。CIは，症例10のみ Nucleus22, ス ピーチプロセッサーは Esprit22, 他は全例 Nucleus 24, スピーチプロセッサーは, 症例 $1 \sim 3,7$ は Freedom, 症例 $4 \sim 6,8,9$ は Esprit3G を装用して おり, 電極数やマッピングに関して, 特記事項は無 かった。CI+HA 群の HA は，全例耳掛け型のデジ タル HA で, HAのフィッティングは, 各補聴器メ 一カーのフィッティングッールを使用し，入力音圧 や周波数に応じて利得が変化するノンリニア増幅を コンピューターで行った。CI埋め込み術施行の平 均年齢は, CI + HA 群 4 歳 5 力月, CI 群 3 歳 11 力 月, $\mathrm{CI}$ 装用平均年数は, $\mathrm{CI}+\mathrm{HA}$ 群 4 年 7 力月, $\mathrm{CI}$ 群 6 年10カ月であった。 VIQ の平均は, $\mathrm{CI}+\mathrm{HA}$ 群 107, CI 群106, SS の平均は, CI+HA群10, CI 群 11であった（表 1 )。

なお，本論文への記載については，各症例の保護 者から同意をいただいている。

\section{方法}

全例，裸耳聴力と装用間值を測定した。裸耳聴力 は純音聴力検査, $\mathrm{CI}$ 装用閾值と $\mathrm{CI}+\mathrm{HA}$ 群の $\mathrm{HA}$

表 1 対象概要

\begin{tabular}{|c|c|c|c|c|c|c|c|}
\hline & 症例 & 性別 & CI 術年齢 & CI 装用年数 & CI 装用耳 & VIQ & SS \\
\hline \multirow{5}{*}{$\begin{array}{c}\mathrm{CI} \\
+ \\
\mathrm{HA} \\
\text { 群 }\end{array}$} & 1 & 男 & 3 歳11力月 & 2 年 6 力月 & 左 & 92 & 9 \\
\hline & 2 & 男 & 2 歳 1 力月 & 4 年 5 力月 & 右 & 118 & 11 \\
\hline & 3 & 男 & 5 歳 6 力月 & 3 年11力月 & 右 & 114 & 11 \\
\hline & 4 & 女 & 3 歳 6 力月 & 7 年 2 力月 & 左 & 110 & 11 \\
\hline & 5 & 女 & 6 歳11力月 & 4 年11力月 & 左 & 99 & 10 \\
\hline \multicolumn{3}{|c|}{$\mathrm{CI}+\mathrm{HA}$ 群平均 } & 4 歳 5 力月 & 4 年 7 カ月 & & 107 & 10 \\
\hline \multirow{5}{*}{$\begin{array}{l}\text { CI } \\
\text { 群 }\end{array}$} & 6 & 女 & 1 歳11力月 & 5 年 5 カ月 & 右 & 108 & 12 \\
\hline & 7 & 男 & 2 歳 1 力月 & 7 年 5 力月 & 左 & 118 & 12 \\
\hline & 8 & 女 & 6 歳 1 力月 & 5 年 5 力月 & 右 & 101 & 10 \\
\hline & 9 & 男 & 6 歳 5 力月 & 5 年 4 力月 & 右 & 110 & 11 \\
\hline & 10 & 男 & 3 歳 3 力月 & 10年 5 カ月 & 左 & 96 & 10 \\
\hline \multicolumn{3}{|c|}{ CI 群平均 } & 3 歳11力月 & 6 年10力月 & & 106 & 11 \\
\hline
\end{tabular}


装用閾值, CI と HA 両耳装用閾值はピープショウ テストで実施した。純音聴力検査に扔いて，スケー ルアウトの場合は，オージオメータの最高出力 + 5 $\mathrm{dB}$ とした。

語音聴取検査は，全例の CI 装用時と $\mathrm{CI}+\mathrm{HA}$ 群 の CI と HA両耳装用時に実施した。CI+HA 群で は，まず，CI装用時の検査を実施し， 1 週間後に CI と HA 両耳装用時の検査を実施した。検查は, 防音室内で, 児から $1 \mathrm{~m}$ 離れた前方に, スピーカ 2 台を横に並べ，各スピーカが児の左右の外耳道の高 さで，左右それぞれの耳の正面から音が出るように 設置した。刺激音はコンピューターを使って 80 dBSPL で提示し, 復唱法か書字によって回答させ た。単音節は 5 母音と 13 子音の計 18 音節を 1 リスト とし, 文章は 1 文が $3 \sim 5$ 文節からなる 10 短文の計 40文節を 1 リストとした。各リストを 1 回ずつ提示 し, 正答数から正答率を算出した。

また，CI+HA 群には，CI と HA 両耳装用時と CI のみ装用時に, ききとりや音への反応に違いがあっ たか，CI 群には，CI 対側耳の HA 非装用となった 理由を口頭で児に確認した。

\section{結果}

1. CI 対側耳裸耳聴力（図 1)

CI 対側耳の裸耳聴力は, 会話域平均 (4 分法) で，CI+HA 群は 97dBHL，CI 群は106dBHLと，9 $\mathrm{dB}$ の差がみられた。周波数別では, $125 \mathrm{~Hz}$ で 13 $\mathrm{dB}, 250 \mathrm{~Hz}$ で $12 \mathrm{~dB}$ の差があり, $2000 \mathrm{~Hz}$ で $12 \mathrm{~dB}$, $4000 \mathrm{~Hz}$ で $17 \mathrm{~dB}, 8000 \mathrm{~Hz}$ で $11 \mathrm{~dB}$ と，低音域と高 音域で $10 \mathrm{~dB}$ 以上の差があり, $\mathrm{CI}+\mathrm{HA}$ 群が良好だ った。

2 . 装用䦭值

1）CI 装用閾值（図 2）

CI 装用闒値は, 会話域平均 (4 分法) で, CI+ HA 群 31dBHL，CI 群 30dBHL であった。周波数別 では，1000Hzで $2 \mathrm{~dB}, 4000 \mathrm{~Hz}$ で $3 \mathrm{~dB} ， \mathrm{CI}$ 群が良 好であった。

2) HA 装用閾值（図 3 )

$\mathrm{CI}+\mathrm{HA}$ 群の $\mathrm{HA}$ 装用閾値は，会話域平均（4 分 法)で，49dBHLだった。周波数別では，500～1000 $\mathrm{Hz}$ は，全例 40～50dBHL 台の装用間值であった が，2000 4000Hz の高周波数域では，装用間值は 40dBHL 台から 60dBHL 台と対象によって差がみら れた。

周波数 $\mathrm{Hz}$
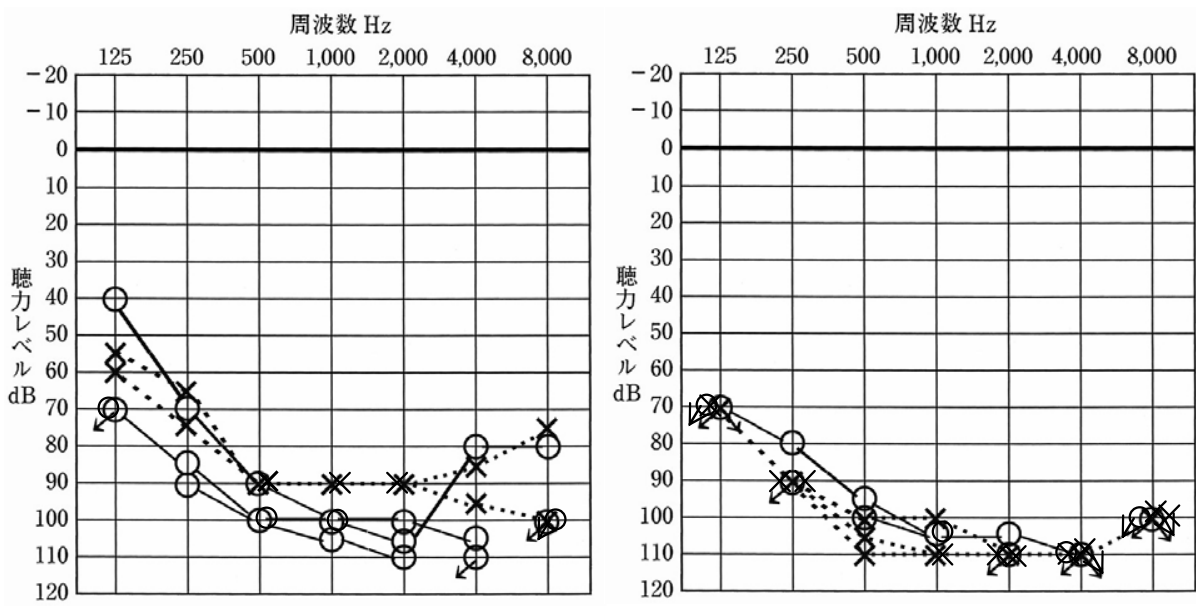

$\mathrm{CI}+\mathrm{HA}$ 群

CI 群

\begin{tabular}{c|l|l|l|l|l|l|l|l}
\hline $\mathrm{Hz}$ & 125 & 250 & 500 & $1 \mathrm{k}$ & $2 \mathrm{k}$ & $4 \mathrm{k}$ & $8 \mathrm{k}$ & 会話域 \\
\hline $\mathrm{CI}+\mathrm{HA}$ 群 & 60 & 77 & 94 & 97 & 99 & 96 & 93 & 97 \\
\hline $\mathrm{CI}$ 群 & 73 & 89 & 102 & 106 & 111 & 113 & 104 & 106 \\
\hline \multicolumn{1}{|c|}{} & \multicolumn{6}{c}{ (平均 dBHL) }
\end{tabular}

図 1 CI 対側耳裸耳聴力 
3）CI と HA 両耳装用閾值（図 4)

$\mathrm{CI}+\mathrm{HA}$ 群の $\mathrm{CI}$ と $\mathrm{HA}$ 両耳装用閾值は, 会話域 平均（4 分法）で $27 \mathrm{dBHL}$ で, CI のみ装用時より $4 \mathrm{~dB}$ の改善がみられた。周波数別では，500Hzは 5 例中 3 例, $1000 \mathrm{~Hz}$ では 5 例全例, $2000 \mathrm{~Hz}$ は 5 例中
1 例闇值が改善, $4000 \mathrm{~Hz}$ では変化がみられなかっ た。

また, $\mathrm{CI}+\mathrm{HA}$ 群の両耳装用時閾値と CI 群の CI 装用閾值を比較すると，会話域平均（4 分法）で 3 $\mathrm{dB}, \mathrm{CI}+\mathrm{HA}$ 群が良好であった。周波数別では，500
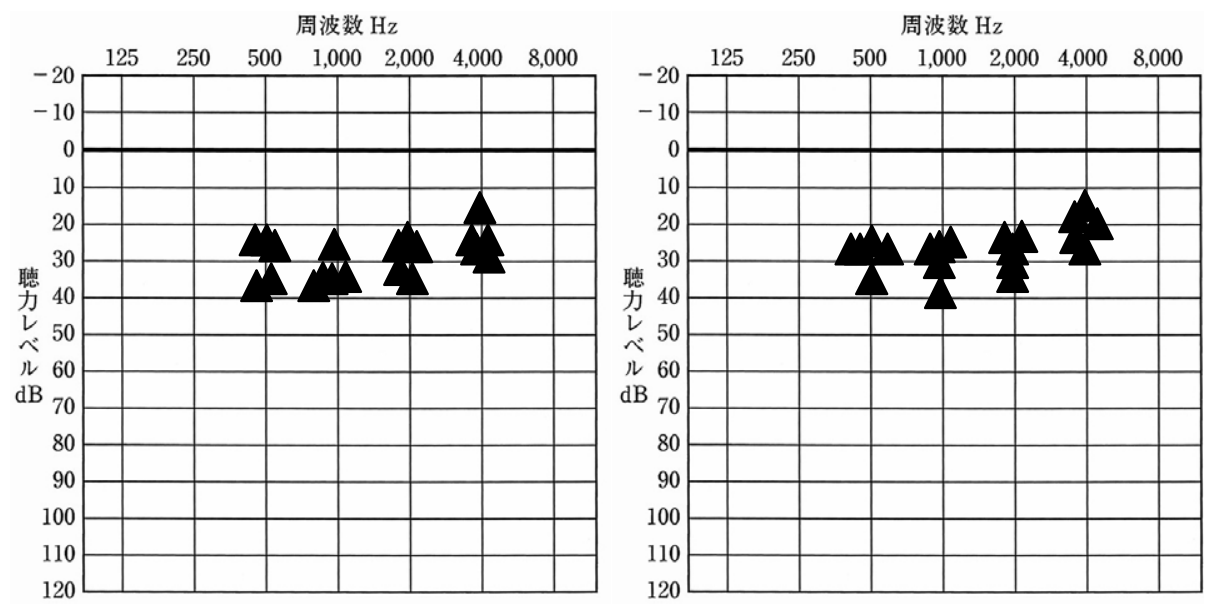

\begin{tabular}{|c|c|c|c|c|c|}
\hline & & & & & 人三域 \\
\hline & & & & & \\
\hline $\mathrm{CI}+\mathrm{HA}$ 群 & 29 & 33 & 29 & 24 & 31 \\
\hline CI 群 & 29 & 31 & 29 & 21 & 30 \\
\hline
\end{tabular}

図2 CI 装用閾值

周波数 $\mathrm{Hz}$

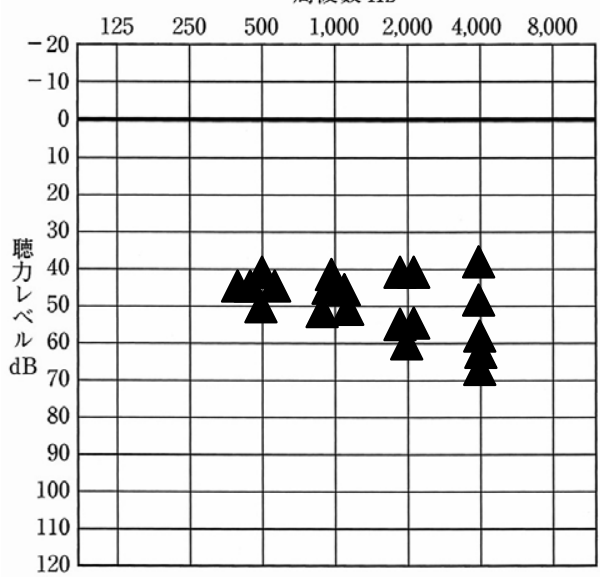

\begin{tabular}{c|l|l|l|l|l}
\hline $\mathrm{Hz}$ & 500 & $1 \mathrm{k}$ & $2 \mathrm{k}$ & $4 \mathrm{k}$ & 会話域 \\
\hline $\mathrm{CI}+\mathrm{HA}$ 群 & 47 & 49 & 52 & 56 & 49 \\
\hline \multicolumn{5}{|c}{} \\
(平均 dBHL)
\end{tabular}

図3 HA 装用閾値

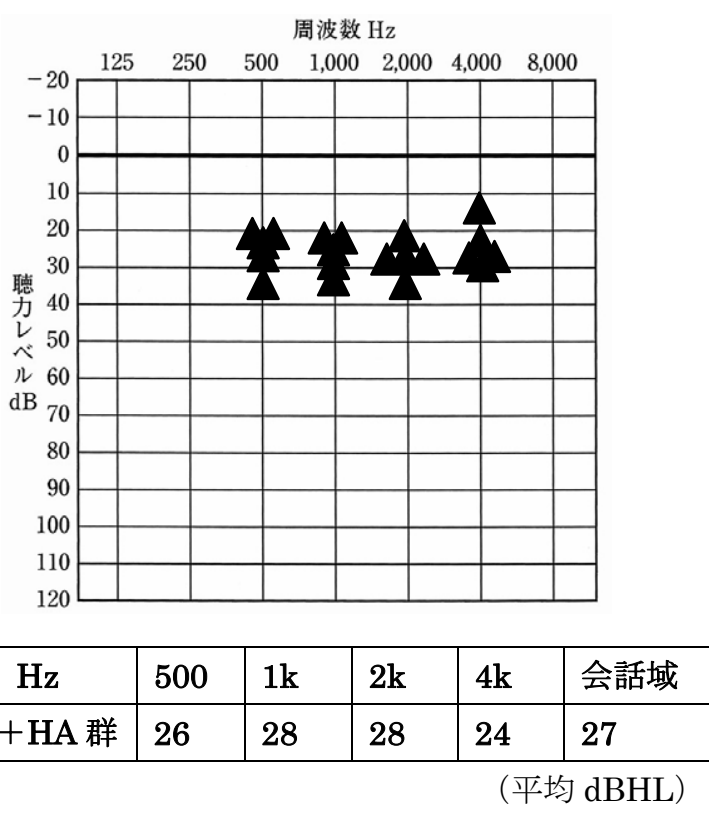

図4 CI+HA 装用時閾值 
$\mathrm{Hz}$ から $2000 \mathrm{~Hz}$ は，1 3 3dB，CI+ HA 群が良好で あったが，4000Hzは，3dB，CI群が良好であった (表 2)。

3 . 語音聴取能力

1 ) 単音節 (図 5 )

$\mathrm{CI}+\mathrm{HA}$ 群の $\mathrm{CI}$ と $\mathrm{HA}$ 両耳装用時は, 平均 $95 \%$ の正答率で, CI 群の正答率は, 平均 $97 \%$ あった。

$\mathrm{CI}+\mathrm{HA}$ 群の $\mathrm{CI}$ の久装用時では，平均 $89 \%$ の正 答率で, $\mathrm{CI}$ と $\mathrm{HA}$ 両耳装用時より, 正答率が低下 する傾向がみられた。

2 ) 文章 (図 6)

文章では, $\mathrm{CI}+\mathrm{HA}$ 群の $\mathrm{CI}$ と $\mathrm{HA}$ 両耳装用時は,
平均 $96 \%$ の正答率で, $\mathrm{CI}$ 群は, 平均 $97 \%$ の正答率 であった。

$\mathrm{CI}+\mathrm{HA}$ 群の $\mathrm{CI}$ のみ装用時は, 平均 $92 \%$ と CI と $\mathrm{HA}$ 両耳装用時より，正答率が若干低下していた。

4. CI 対側耳の HA 装用時の感想・HA 非装用理由 (表 3)

$\mathrm{CI}+\mathrm{HA}$ 群に対する, CI 対側耳の HA についての ききとり調査の結果では，HAがある時とない時で の違いに関しては，音に関して 2 例，ことばに関し て 2 例が，HAを装用してきこえが改善することを あげており，1例が HA を装用した方がいいという 回答だった。

表2 聴力・装用閾值

\begin{tabular}{|c|c|c|c|c|c|c|}
\hline & 症例 & 裸耳（CI 側） & 裸耳（対側） & CI 装用 & $\mathrm{CI} \cdot \mathrm{HA}$ 装用 & $\mathrm{HA}$ 装用 \\
\hline \multirow{5}{*}{$\begin{array}{c}\mathrm{CI}+\mathrm{HA} \\
\quad \text { 群 }\end{array}$} & 1 & $104 \mathrm{~dB}$ & $101 \mathrm{~dB}$ & $35 \mathrm{~dB}$ & $33 \mathrm{~dB}$ & $45 \mathrm{~dB}$ \\
\hline & 2 & $115 \mathrm{~dB}$ & $90 \mathrm{~dB}$ & $29 \mathrm{~dB}$ & $24 \mathrm{~dB}$ & $50 \mathrm{~dB}$ \\
\hline & 3 & $108 \mathrm{~dB}$ & $90 \mathrm{~dB}$ & $29 \mathrm{~dB}$ & $25 \mathrm{~dB}$ & $53 \mathrm{~dB}$ \\
\hline & 4 & $106 \mathrm{~dB}$ & $105 \mathrm{~dB}$ & $25 \mathrm{~dB}$ & $23 \mathrm{~dB}$ & $55 \mathrm{~dB}$ \\
\hline & 5 & $114 \mathrm{~dB}$ & $98 \mathrm{~dB}$ & $36 \mathrm{~dB}$ & $31 \mathrm{~dB}$ & $44 \mathrm{~dB}$ \\
\hline \multicolumn{2}{|c|}{$\mathrm{CI}+\mathrm{HA}$ 群平均 } & $109 \mathrm{~dB}$ & $97 \mathrm{~dB}$ & $31 \mathrm{~dB}$ & $27 \mathrm{~dB}$ & $49 \mathrm{~dB}$ \\
\hline \multirow{5}{*}{ CI 群 } & 6 & $109 \mathrm{~dB}$ & $103 \mathrm{~dB}$ & $24 \mathrm{~dB}$ & & \\
\hline & 7 & $115 \mathrm{~dB}$ & $104 \mathrm{~dB}$ & $27 \mathrm{~dB}$ & & \\
\hline & 8 & $114 \mathrm{~dB}$ & $109 \mathrm{~dB}$ & $28 \mathrm{~dB}$ & & \\
\hline & 9 & $110 \mathrm{~dB}$ & $110 \mathrm{~dB}$ & $31 \mathrm{~dB}$ & & \\
\hline & 10 & $115 \mathrm{~dB}$ & $105 \mathrm{~dB}$ & $39 \mathrm{~dB}$ & & \\
\hline \multicolumn{2}{|c|}{ CI 群平均 } & $113 \mathrm{~dB}$ & $106 \mathrm{~dB}$ & $30 \mathrm{~dB}$ & & \\
\hline
\end{tabular}

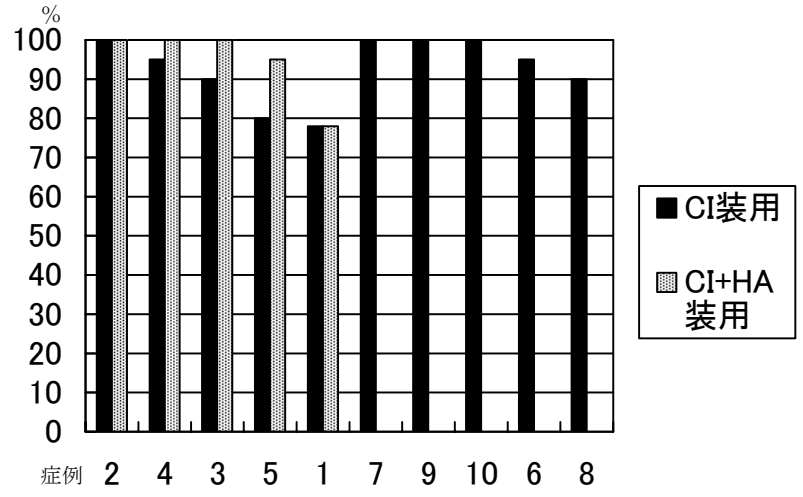

図5 語音聴取 (単音節)

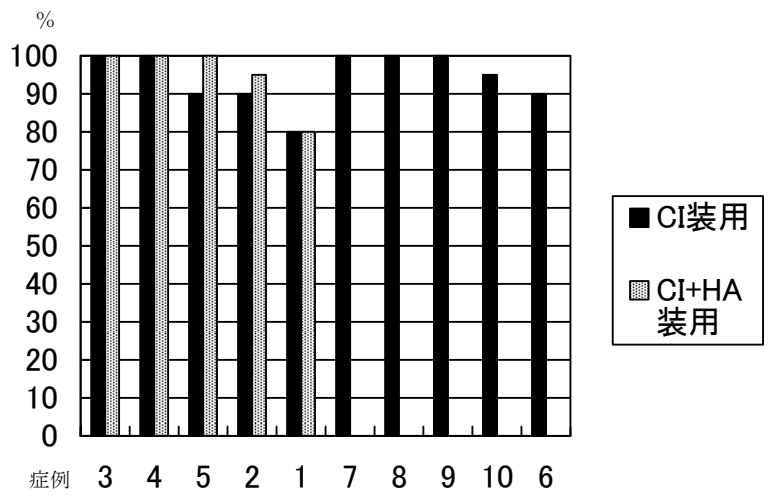

図6 語音聴取（文章） 
表 3 HA 装用の感想・非装用の理由

\begin{tabular}{l|c|l}
\hline & 症例 & \multicolumn{1}{c}{ 内容 } \\
\hline \multirow{5}{*}{ CI+HA 群 } & 1 & HAをつけるといい (違う $)$ \\
\cline { 2 - 3 } & 2 & 音がよくきこえる \\
\cline { 2 - 3 } & 3 & ことばがききとりやすい \\
\cline { 2 - 3 } & 4 & 低い音がよくきこえる \\
\cline { 2 - 3 } & 5 & ことばがはっきりする \\
\hline \multirow{5}{*}{ CI 群 } & 6 & つけるとうるさくなる \\
\cline { 2 - 3 } & 7 & ことばがききにくくなる \\
\cline { 2 - 3 } & 8 & 音が大きくてうるさい \\
\cline { 2 - 3 } & 9 & ことばが変にきこえる \\
\cline { 2 - 3 } & 10 & 周りの音がうるさい \\
\hline
\end{tabular}

CI 群の CI 対側耳の HA の非装用理由では, HA を装用したら，「うるさくなる」が 3 例，「ことばが ききとりにくくなる」が2例で，全例 HA 装用時の きこえに対して否定的な回答があげられた。

\section{考察}

\section{1. $\mathrm{CI}+\mathrm{HA}$ 群と CI 群の比較}

$\mathrm{CI}$ 対側耳の裸耳聴力は, $\mathrm{CI}+\mathrm{HA}$ 群 5 例中 3 例が 平均聴力で 90dBHL台であり, 全体としても, CI +HA 群はCI群より良好だった。CI装用閾值で は，会話域平均で， $1 \mathrm{~dB}$ 程度 $\mathrm{CI}$ 群が良好であった が，CI+HA 群は，CI と HA の両耳装用時に装用闇 值の若干の改善がみられ, 会話域平均では, $3 \mathrm{~dB}$ 程 度 CI 群より良好であった。

語音聴取においては，単音節，文章とも，CI 群 の正答率が平均 $97 \%$ と若干良好であった。CI+HA 群は, $\mathrm{CI}$ と $\mathrm{HA}$ の両耳装用時の正答率の平均は CI 群と 1 〜 \%の差であったが，HAを外した CIの み装用時では，CI と HA の両耳装用時から正答率 の平均は 4〜 6\%低下していた。

CIのみ装用時では, CI 装用閾值, 語音聴取とも, $\mathrm{CI}$ 群が CI+ HA 群より良好な結果であった。これ は，CI 群は，CI のみ装用でもききとりは良好であ り，それが HA 非装用につながっている可能性も考 えられた。

一方，CI+HA 群において，CIのみ装用時の聴取 成績が CI 群より悪い原因として，富澤らは，CI は
高音域に優位であり，HA は低音域に優位で，両者 は語音聴取における周波数情報の利用の仕方が異な ると考察しており を常に併用し，日常的に HA からの聴覚情報を併せ て処理していると考えられる。したがって，HAを 非装用にした CI のみ装用時では，HAからの聴覚 情報が得られないため, 成績が低下し，CI+HA群 では，HAからの聴覚情報が活用できており，CI 対 側耳にHA を装用することで，HAの装用効果が得 られていると推測される。

これらのことから，CI+ HA 群では, 装用閾值, 語音聴取とも，HAを併用することで改善してお り，HAの装用効果が得られていると考えられた。 このため, CI 対側耳の裸耳聴力が 90dBHL 台であ れば, CI 対側耳に HA を装用できる可能性があ り, 両耳補聴効果が期待できるのではないかと推測 された。

\section{2. 再耳補聴効果}

聴力レベルや装用閾值が左右で同程度の場合，裸 耳や HA 両耳装用の両耳補聴効果として, 両耳加算 効果, 両耳融合効果, 両耳分離効果等があげられて

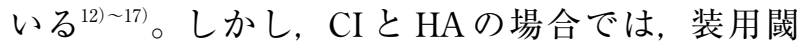
值に差があり，振幅と位相の同じ音が同時に入って きた場合に起こるとされる両耳加算効果は期待しづ らい。語音聴取に関わる両耳融合効果，騒音下での ききとりに関わる両耳分離効果については, 富澤ら は, CI と対側耳 HA の両耳補聴効果として, 語音 聴取が改善し, 両耳融合効果が働いていると指摘7),8 しており, Morera $ら^{3)}$, Luntz $ら^{4,6)}$, 松代 ${ }^{9)}$ は, 成人での CI と対側耳 HA の両耳装用例で, 騒音下 でのききとりの向上を認め, これは両耳分離効果が 㗢いているとしている。

今回の症例では, CI と対側耳 HA の両耳装用に よって, 語音聴取能力と装用閾值の改善がみられ た。語音聴取能力の改善については, $\mathrm{CI}+\mathrm{HA}$ 群の CI と HA 両耳装用時において, 単音節, 文章とも 正答率が向上しており，正答率が下がった例はみら れなかったことから，両耳融合効果が働いていると 考えられる。

しかし，装用閾值の改善については，CI 装用閾 值と HA 装用閾值に，会話域平均で $18 \mathrm{~dB}$ の差があ るため, CI と対側耳 HA の両耳装用による $4 \mathrm{~dB}$ の 
閾值改善が，両耳加算の効果であるのか，測定誤差 であるのかは明確ではなく, 今後, より多くの症例 での詳細な検討が必要であると考えられる。

また，小児の場合，騷音下での語音聴取検査は， 聴力や装用閾值に加えて, 言語能力や知的諸能力と いったトップダウン処理能力の発達も影響すると考 えられる。健聴児の場合, 両耳分離能検查では, 3 歳児の成績が最も悪く，4歳以降で成績が向上する が, 成人の域に達するのは 7 歳以後と思われた ${ }^{18)}$ と いう報告があり，CI と対側耳 HA の両耳装用児の 場合には, 装用何年で検査の実施が可能となるか, 両耳分離効果がはっきりしてくるか等について，言 語能力や知的諸能力の発達, 生活年齢, 装用年数等 を考慮に入れながら, 総合的に検討していく必要が ある。このため, 今回の症例では, 騷音下での語音 聴取検查は検討外としたが，小児の CI と HA 両耳 装用時の騒音下での語音聴取能力に関しても, 今後 の検討課題である。

これらから, 小児の CI と対側耳 HAの両耳補聴 効果としては, 両耳融合という点で効果があり, 両 耳加算や両耳分離等の効果に関しては, 今後, 詳細 に検討していく必要があると考えられた。

3. CI 対側耳の HA 装用

CI 対側耳の HA 装用に関して, 日本における CI の導入初期には，CI 対側耳への HA 装用は，HA装 用効果を全く期待できない症例に適応してきたこと や，CI と HA の信号の伝達システムや音質の違い が，中枢レベルで拮抗を生じ聴取に混乱をきたす可 能性を危惧し，あまりいい方法ではないと考えられ ていた ${ }^{19)}$ 。しかし，2006年以降は，日本耳鼻咽喉科 学会の適応基準の変更 ${ }^{20)}$ により, 両耳の平均聴力 90 dBHL 以上の児に適応されるようになった。このこ とにより，残聴を有しており，HAからの装用効果 を期待できる児に，CIが適応されるようになって きた。また，デジタル HAの普及・HA 性能の向上 等も, CI と対側耳 HA の両耳装用への効果を期待 させ, 事実, CI と対側耳 HA の両耳装用で, 成人 の語音聴取や騒音下でのききとりの向上，小児での 語音聴取の向上等において, 好結果を得られたとい う報告も多くみられる ${ }^{3) \sim 11,211 。}$

今回の症例でも, CI と対側耳 HAの両耳装用を している $\mathrm{CI}+\mathrm{HA}$ 群は，5例中 4 例が $\mathrm{CI}$ 対側耳の
HA装用によってきこえが改善すると感じてお り，1例は HA を装用する方がよいという回答で, 児の側もHAの装用効果を自覚していた。このよう に，CI と HA の併用を勧める対象症例としては，1) 対側耳に残聴がある例，2）対側耳の補聴効果がよ い例，3）両耳聴を望んでいる例，4）すべての幼児 （対側の聴力の評価が困難であるので）があげられ ている22)。また, HA 併用の条件としては, 残存聴 力があること, HAの増幅が大きすぎないことも重 要で, HAの微調整も必要になるという指摘 ${ }^{23)} も あ$ る。これに関しては, 今回の CI 群では, 全例, 残 存聴力という点において, $\mathrm{CI}+\mathrm{HA}$ 群に比べ劣って いたが，CI 対側耳に HA を装用すると，「うるさく なる」，「きこえにくくなる」と否定的な回答で，HA 装用を嫌がっていた。これらから，児の自覚的な HA 装用効果も，HAの装用・非装用に影響している可 能性があり, 児の HA 装用に対する感想も装用指導 においては無視できず，上記の増幅が大きすぎる， あるいは微調整が必要という指摘に従えば，HAに 調整を加えることで，HA 装用継続が可能になった かもしれない。したがって，本人の訴えを傾聴する ことも，小児例であっても重要な作業と考えられ る。さらに，CI と対側耳にHA を併用する両耳補 聴効果が，すべての人にみられるわけではないとい

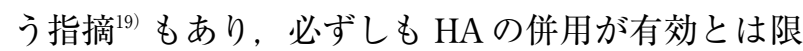
らないので，HA装用指導の際には考慮に入れてお く必要があると考えられる。

以上のことから, 今回の症例のような CI 対側耳 に 90dBHL 台の残聴があり, HA 装用効果が期待で きる CI 装用児は, 今後増加していくことが予想さ れ，これらの児においては，CI 対側耳の HA装用 をまずは試み，CI 対側耳の HA 装用による両耳補 聴効果を, 継時的に評価し, HA についても調整を 行う必要がある。つまり, CI のハビリテーション において，CI 対側耳への HA 装用は, CI 対側耳の 裸耳聴力や語音聴取能力の評価が重要であり, CI と HA 両耳装用時の児の反応や児の HA に対する感 想等も, 十分考慮しながら指導を行っていく必要が あると考えられた。

$$
\text { ま と め }
$$

1. $\mathrm{CI}+\mathrm{HA}$ 群は, $\mathrm{CI}$ 対側耳の裸耳聴力が平均 90 
dBHL台であり，CI 群より良好であった。

2. $\mathrm{CI}+\mathrm{HA}$ 群の $\mathrm{CI}$ と対側耳 $\mathrm{HA}$ の両耳装用では, CI 単独装用時に比べて語音聴取検査成績の改善を 認めた。

3. $\mathrm{CI}+\mathrm{HA}$ 群では，児が CI 対側耳への $\mathrm{HA}$ 装用 を嫌がらず，きこえの改善を自覚していた。また， CI 群では，児が CI 対側耳への HA 装用に対して否 定的であった。

4. CI 対側耳への HA 装用は, CI 対側耳が HA 装 用によって聴覚活用可能かどうかの裸耳聴力の評価 と, CI と対側耳 HA の両耳装用による補聴効果の 評価が重要であり，児の感想等も考慮して装用指導 する必要があると考えられた。

本論文の要旨は，第54回日本聴覚医学会学術講演 会において，口演した。

\section{Binaural hearing effect in children wearing cochlear implants and hearing aids \\ -Comparison with children wearing only cochlear implants-}

Naoe Mori $^{1{ }^{1 / 2)}}$, Juichi Ito $^{1)}$, Toshiko Mori ${ }^{2), 3)}$, Harukazu Hiraumi ${ }^{1)}$, Shinobu Yamaguchi ${ }^{4}$, Michiru Ishimaru ${ }^{5)}$, Kyoko Ito $^{1)}$, Akiko Onishi ${ }^{11}$, Seiko Kuroda ${ }^{6}$, Masaaki Fujimoto ${ }^{2}$

${ }^{1)}$ Department of Otolaryngology, Head and Neck Surgery, Graduate School of Medicine, Kyoto University

${ }^{2)}$ Fujimoto clinic of Otolaryngology

${ }^{3}$ Health Science University of Hokkaido Graduate School of Speech-language and Hearing Disorders

${ }^{4)}$ Department of Communication Disorders, Faculty of Health Care Science, Himeji Dokkyo University

${ }^{5}$ Department of Otolaryngology, Japanese Red Cross Society Wakayama Medical Center

${ }^{6}$ Department of Speech-Language Pathology and Audiology, Faculty of Medical Science for Health, Teikyo Heisei University
Abstract: We compared 5 children wearing a cochlear implant plus hearing aid $(\mathrm{CI}+\mathrm{HA})$ with 5 children wearing a cochlear implant alone $(\mathrm{CI})$ in terms of the hearing acuity of the non-implanted ear, the hearing threshold, and the speech intelligibility. The following differences were observed between the CI + HA group and the CI group.

It was found that in the $\mathrm{CI}+\mathrm{HA}$ group, the average pure-tone hearing level of the non-implanted ear was about $90 \mathrm{dBHL}$; therefore, the average speech intelligibility of the CI+ HA group was better than that of the CI group.

It was also found that the children in the $\mathrm{CI}+$ HA group realized that their hearing improved with the wearing of the cochlear implant and hearing aid, whereas the children in the CI group were unwilling to wear a hearing aid in the non-implanted ear because they did not realize the effectiveness of a hearing aid. Therefore, it is important to evaluate the hearing acuity of the non-implanted ear and the binaural hearing effectiveness with the wearing of a cochlear implant and hearing aid. Furthermore, we should consider the necessity of a hearing aid for the non-implanted ear through observation of the auditory responses in children, and perform counseling for the children.

\section{参考文献}

1) Litovsky RY, Johnstone PM, Godar SP: Benefits of bilateral cochlear implants and/or hearing aids in children. Int J Audiol 45: S78-91, 2006

2) Van Deun L, Van Wieringen A, Francart T, et al: Bilateral cochlear implants in children : binaural unmasking. Audiol Neurootol 14: 240-247, 2009

3 ) Morera C, Manrique M, Ramos A, et al: Advantages of binaural hearing provided through bimodal stimulation via a cochlear implant and a conventional hearing aid : a 6-month comparative study. Acta Otolaryngol 125 : 596-606, 2005

4) Luntz M, Shpak T, Weiss H : Binaural-bimodal 
hearing : concomitant use of a unilateral cochlear implant and a contralateral hearing aid. Acta Otolaryngol 125 : 863-869, 2005

5 ) Francart T, Brokx J, Wouters J : Sensitivity to interaural level difference and loudness growth with bilateral bimodal stimulation. Audiol Neurootol 13 : 309-319, 2008

6 ) Luntz M, Yehudai N, Shpak T: Hearing progress and fluctuations in bimodal-binaural hearing users (unilateral cochlear implants and contralateral hearing aid). Acta Otolaryngol 127 : 1045-1050, 2007

7 ）富澤晃文, 木下眞理, 加藤大典：人工内耳と補 聴器を併用した聴覚障害児の聴取様態一両耳融合 の観点から一。Audiology Japan 47:617-623, 2004

8 ）富澤晃文, 加藤靖佳 : 人工内耳と補聴器の併用 による両耳聴：聴覚障害児 1 事例の聴取様態につ いて。心身障害学研究 $26: 45-52,2002$

9 ）松代直樹, 佐藤崇, 井脇貴子, 他：人工内耳と 補聴器の両耳装用に扔ける両耳聴効果について 語音聴取能（67-S 語表，Japanese HINT）に関す る検討。日本耳鼻咽喉科学会会報 106 ：211219, 2003

10）松代直樹, 佐藤崇, 安岡絵理, 他：人工内耳と 補聴器の両耳装用における両耳聴効果について 方向感に関する検討。Otology Japan 13:337, 2003

11) Ching TY, Psarros C, Hill M, et al : Should children who use cochlear implants wear hearing aids in opposite ear? Ear \&Hearing 22 : 365-380, 2001

12）太田文彦：両耳合成能と両耳分離能。日耳鼻 69 補 3:27-50, 1966

13）佐藤恒正，設楽哲也，富沢正雄，他：両耳融合 に関する二，三の知見。Audiology Japan 13:7990, 1970

14) Durlach NI, Colburn HS : Binaural phenomena. Handbook of Perception Vol.4, Carterette EC, Friedman MP (eds). New York Academic Press, 365-466, 1978
15）切替一郎，野村恭也：耳科学第 3 章耳の生理。 新耳鼻咽喉科学, 南山堂, 2004

16) Byrne D : Clinical issues and options in binaural hearing aid fitting. Ear and Hearing 2 : 187193, 1981

17）神田幸彦, 城戸由美子, 松永倫子, 他：補聴器 の両耳装用。JOHNS 24：1337-1340, 2008

18）永㴊正昭：幼児の両耳分離能と一側耳分離能に 関する研究。日本耳鼻咽喉科学会会報 73:133144, 1973

19）伊藤寿一：人工内耳に関する $\mathrm{Q} \& \mathrm{~A} 。 人 工 内 耳$ 改訂第 2 版 (本庄嚴編著), 中山書店, 243-249, 1999

20）日本耳鼻咽喉科学会福祉医療 - 乳幼児委員会： 小児人工内耳適応基準。日耳鼻 109：506-507, 2006

21）細井裕司：補聴器の適合（人工内耳との併用を 含む)。日本耳鼻咽喉科學會會報 110 : 484487, 2007

22) Offeciers E, Morera C, Muller J, et al : International consensus on bilateral cochlear implants and bimodal stimulation. Acta Oto-Laryngologica 125 : 918-919, 2005

23）城間将江，山岨達也，加我君孝：小児人工内耳 の長期的言語聴取能力に寄与する要因：文献考 察。ENTONI 27: 46-63, 2003

（原稿受付 平成22.2.8）

別冊請求先 : ₹ 606-8507

京都市左京区聖護院川原町54

京都大学大学院医学研究科耳鼻咽喉 科・頭頸部外科

森尚彫

\section{Reprint request :}

Naoe Mori

54 Syogoin kawahara-cho, Sakyo-ku, Kyoto-shi, 606-8507, JAPAN

Department of Otolaryngology-Head and Neck Surgery, Graduate School of Medicine, Kyoto University 